Article

\title{
Cytosolic Isocitrate Dehydrogenase from Arabidopsis thaliana Is Regulated by Glutathionylation
}

\author{
Adnan Khan Niazi 1,2,3 ${ }^{\text {D }}$, Laetitia Bariat ${ }^{1,2}$, Christophe Riondet ${ }^{1,2}$, Christine Carapito ${ }^{4}$, \\ Amna Mhamdi 5,6,7, Graham Noctor ${ }^{5}$ and Jean-Philippe Reichheld 1,2,* \\ 1 Laboratoire Génome et Développement des Plantes, Université Perpignan Via Domitia, \\ F-66860 Perpignan, France; niazi@uaf.edu.pk (A.K.N.); laetitia.bariat@univ-perp.fr (L.B.); \\ christophe.riondet@univ-perp.fr (C.R.) \\ 2 Laboratoire Génome et Développement des Plantes, CNRS, F-66860 Perpignan, France \\ 3 Centre of Agricultural Biochemistry and Biotechnology, University of Agriculture Faisalabad, \\ 38000 Faisalabad, Pakistan \\ 4 Laboratoire de Spectrométrie de Masse BioOrganique (LSMBO), IPHC, Université de Strasbourg, \\ CNRS UMR 7178, 67037 Strasbourg, France; ccarapito@unistra.fr \\ 5 Institute of Plant Sciences Paris Saclay IPS2, Université Paris-Sud, CNRS, INRA, Université Evry, \\ Paris Diderot, Sorbonne Paris-Cité, Université Paris-Saclay, Bâtiment 630, 91405 Orsay, France; \\ amna.mhamdi@psb.vib-ugent.be (A.M.); graham.noctor@u-psud.fr (G.N.) \\ 6 Department of Plant Biotechnology and Bioinformatics, Ghent University, 9052 Gent, Belgium \\ 7 Center for Plant Systems Biology, VIB, 9052 Gent, Belgium \\ * Correspondence: jpr@univ-perp.fr; Tel: +33-468-662-225; Fax: +33-468-668-499
}

Received: 15 November 2018; Accepted: 22 December 2018; Published: 8 January 2019

check for updates

\begin{abstract}
NADP-dependent (Nicotinamide Adénine Dinucléotide Phosphate-dependent) isocitrate dehydrogenases (NADP-ICDH) are metabolic enzymes involved in 2-oxoglutarate biosynthesis, but they also supply cells with NADPH. Different NADP-ICDH genes are found in Arabidopsis among which a single gene encodes for a cytosolic ICDH (cICDH) isoform. Here, we show that cICDH is susceptible to oxidation and that several cysteine (Cys) residues are prone to S-nitrosylation upon nitrosoglutathione (GSNO) treatment. Moreover, we identified a single S-glutathionylated cysteine Cys363 by mass-spectrometry analyses. Modeling analyses suggest that Cys363 is not located in the close proximity of the cICDH active site. In addition, mutation of Cys363 consistently does not modify the activity of cICDH. However, it does affect the sensitivity of the enzyme to GSNO, indicating that S-glutathionylation of Cys363 is involved in the inhibition of cICDH activity upon GSNO treatments. We also show that glutaredoxin are able to rescue the GSNO-dependent inhibition of cICDH activity, suggesting that they act as a deglutathionylation system in vitro. The glutaredoxin system, conversely to the thioredoxin system, is able to remove S-nitrosothiol adducts from cICDH. Finally, NADP-ICDH activities were decreased both in a catalase 2 mutant and in mutants affected in thiol reduction systems, suggesting a role of the thiol reduction systems to protect NADP-ICDH activities in planta. In line with our observations in Arabidopsis, we found that the human recombinant NADP-ICDH activity is also sensitive to oxidation in vitro, suggesting that this redox mechanism might be shared by other ICDH isoforms.
\end{abstract}

Keywords: Isocitrate dehydrogenase; glutathionylation; nitrosylation; glutaredoxin; Arabidopsis thaliana 


\section{Introduction}

Isocitrate dehydrogenases (ICDHs) reversibly catalyze the oxidative decarboxylation of isocitrate to 2-oxoglutarate (2-OG), a key compound in ammonia assimilation by the glutamine synthetase/glutamate synthase pathway. Through their catalytic activity, ICDHs reduce $\mathrm{NAD}^{+}$or $\mathrm{NADP}^{+}$, producing NADH or NADPH respectively [1,2]. In plants, both NAD and NADP-dependent $\mathrm{ICDH}$ isoforms are found. The NAD-dependent isoform is restricted to mitochondria, where it takes part in the tricarboxylic acid (TCA) cycle [3]. NADP-dependent ICDH isoforms are found in the cytosol, chloroplasts, mitochondria and peroxisomes [4]. In the dicot plant Arabidopsis thaliana, a single isoform is found in each cell compartment. The cytosolic isoform (cICDH) is the most abundant form in leaves, as it is responsible for more than $80 \%$ of the extractible ICDH activity $[5,6]$. Biochemical analyses have shown that both mitochondrial ICDH and cytosolic CICDH activities are dependent on the nitrogen status. As both isoforms are involved in nitrogen assimilation, they have been proposed to have overlapping functions [1,2].

NADH and NADPH produced by ICDH are important in reducing equivalents for the regeneration of thiol reduction enzymes like glutathione, thioredoxin or GSNO-reductases [7,8]. Therefore, ICDH have been proposed to play an antioxidant role against oxidative stress, and damage to ICDH may result in the perturbation of the balance between oxidants and antioxidants, and lead to pro-oxidant conditions. This was shown in mammals, where the cytosolic ICDH isoform is highly reactive to peroxynitrite, affecting its activity by formation of nitrotyrosine and S-nitrosothiol adducts $[9,10]$. Another study in mammalian cells shows that the cytosolic NADP-ICDH activity is regulated by S-glutathionylation [11].

Moreover in mammals, cysteine residues of ICDH play an essential role in the catalytic function of ICDH. Such regulation was not explored in plant isoforms, but evidence suggested that ICDH isoforms can also be redox regulated. Several ICDH isoforms were found to exhibit sulfenylated [12,13], glutathionylated [14] or nitrosylated [15] Cys, suggesting that ICDH cysteines are redox sensitive. Moreover, ICDHs were identified as interactors of thioredoxin (TRX) or glutaredoxin (GRX) in different proteomic approaches [16-20]. Another piece of evidence came from the analyses of a cICDH knock-out mutant in Arabidopsis. cICDH protein is dispensable for plant growth and for the leaf basic metabolism. However, cicdh mutants exhibit accumulation of defense gene transcripts in the absence of pathogen attack and exacerbate the phenotype and the redox perturbation of the oxidative stress mutant catalase 2 (cat2). cat2 is inactivated in the major leaf catalase isoform, which increases the availability of $\mathrm{H}_{2} \mathrm{O}_{2}$ produced in the peroxisomes [6].

Here, we examine the redox sensitivity of the Arabidopsis cytosolic cICDH isoform. We show that enzyme activity is affected by oxidative agents like oxidized glutathione (GSSG) and nitrosoglutathione (GSNO), through modifications of conserved Cys residues in the protein. In particular, Cys363 is S-glutathionylated and can be reversed by the glutaredoxin system. Our data indicate that cytosolic $\mathrm{ICDH}$ is redox regulated and that this regulation might be shared in other organisms.

\section{Materials and Methods}

\subsection{Plant Materials and Growth Conditions}

All Arabidopsis thaliana lines used in this study were of Columbia-0 (Col-0) ecotype. The plants were grown in soil in a controlled growth chamber $\left(180 \mu \mathrm{E} \mathrm{m}^{-2} \mathrm{~s}^{-1}, 16 \mathrm{~h}\right.$ day $/ 8 \mathrm{~h}$ night, $22{ }^{\circ} \mathrm{C} 55 \% \mathrm{RH}$ day, $20{ }^{\circ} \mathrm{C} 60 \% \mathrm{RH}$ night) up to 3 weeks. Plant mutant lines used in this study $n t r a n t r b$, cat2, gr1, gr1 cat2, icdh, icdh cat2, gsnor, nox1, noa1, nia1 nia2 and nia1 nia2 noa 1 were previously described [6,21-28].

\subsection{In Vitro Protein-Based Complementation and TRX/GRX Activity Assays}

For in vitro protein-based TRX complementation assays, $4.38 \mu \mathrm{M}(200 \mathrm{ng} / \mu \mathrm{L})$ recombinant cICDH protein was incubated in $25 \mu \mathrm{L}$ for $2 \mathrm{~h}$ on ice with $1 \mathrm{mM}$ NADPH, $4.59 \mu \mathrm{M}$ TRXh3 or TRXh5 and $3.12 \mu \mathrm{M}$ NADPH-Dependent Thioredoxin Reductase A (NTRA). This reaction mixture was diluted 40 
times in $100 \mathrm{mM}$ phosphate buffer (KOH (Potassium hydroxyde), $\mathrm{pH} 7.5)$ and the ICDH activity assay was performed as described above.

For in vitro protein-based GRX complementation assays, $4.38 \mu \mathrm{M}(200 \mathrm{ng} / \mu \mathrm{L})$ recombinant cICDH was incubated in $25 \mu \mathrm{L}$ for $2 \mathrm{~h}$ on ice with $1 \mathrm{mM}$ NADPH, $5 \mu \mathrm{M}$ GRXC1 or GRXC2, $0.8 \mathrm{mM}$ GSH and $5 \mu \mathrm{M}$ Glutaredoxin Reductase (GR). This reaction mixture was diluted 40 times in $100 \mathrm{mM}$ phosphate buffer $(\mathrm{KOH}, \mathrm{pH} 7.5)$ and the ICDH activity assay was performed as described above.

\subsection{Cloning, Expression and Purification of Recombinant cICDH}

The cICDH-coding sequence (At1g65930), with NdeI and BamHI restriction sites at the N-and C-terminal ends was inserted into pET16b vector (Novagen). Point mutation of cysteine 363 to serine was generated using QuikChange II Directed Mutagenesis Kit (Agilent) using primers detailed in Supplemental Table S1. The constructs were transferred into E. coli BL21 stain and transformed cells were cultured at $37^{\circ} \mathrm{C}$ until $A_{600}=0.7$. cICDH expression was induced by the addition of $1 \mathrm{mM}$ isopropyl-1-thio-d-galactopyranoside (IPTG), followed by further culture at $21^{\circ} \mathrm{C}$ for $16 \mathrm{~h}$. All the steps for the purification of recombinant His-tagged cICDH were performed at $4{ }^{\circ} \mathrm{C}$ as previously described [29]. Briefly, the cells were resuspended in $50 \mathrm{mM}$ Tris- $\mathrm{HCl} \mathrm{pH} \mathrm{7.5,} \mathrm{disrupted} \mathrm{by} \mathrm{sonication,}$ and centrifuged at $125,000 \times g$ for $30 \mathrm{~min}$ at $4{ }^{\circ} \mathrm{C}$. The supernatant was loaded onto the $\mathrm{Ni}^{2+}{ }_{-}$Sepharose column equilibrated with $50 \mathrm{mM}$ Tris- $\mathrm{HCl}, \mathrm{pH} 7.5,200 \mathrm{mM} \mathrm{NaCl}$. The obtained fractions containing the purified protein were collected and evaluated on a SDS-PAGE (Sodium dodecyl sulfate-polyacrylamide gel electrophoresis) gel. Purified recombinant protein samples were pooled and stored at $4{ }^{\circ} \mathrm{C}$.

\subsection{Protein Extracts from Arabidopsis Plants and cICDH Enzymatic Assay}

To perform enzymatic assays, Arabidopsis leaf protein extracts were prepared as described before [30,31]. Briefly, $100 \mathrm{mg}$ leaves were ground in a mortar in liquid nitrogen and resuspended in $0.5 \mathrm{~mL}$ of a buffer containing $50 \mathrm{mM}$ Hepes/KOH, pH 7.4, $1 \mathrm{mM}$ EDTA, $1 \mathrm{mM}$ EGTA, $2 \mathrm{mM}$ Benzamidine, $2 \mathrm{mM} \varepsilon$-aminocaproic acid, $0.5 \mathrm{mM}$ PMSF, 10\% glycerol, $0.1 \%$ Triton X-100 and 1 tablet of EDTA-free protease inhibitor cocktail (Roche). After $15 \mathrm{~min}$ of incubation on ice, samples were centrifuged at $15,000 \times \mathrm{g}$ and at $4{ }^{\circ} \mathrm{C}$ for $15 \mathrm{~min}$ to remove tissue debris. NADP-ICDH activity was measured at room temperature from $40 \mu \mathrm{g}$ of protein extracts in total of $1 \mathrm{~mL}$ reaction medium, having $100 \mathrm{mM}$ phosphate buffer (KOH, pH 7.5), $5 \mathrm{mM} \mathrm{MgCl}_{2}, 250 \mu \mathrm{M}$ of $\mathrm{NADP}^{+}$and $2.5 \mathrm{mM}$ DL-isocitric acid. The activity was monitored as a change in absorbance at $340 \mathrm{~nm}$ due to the isocitrate-dependent rate of $\mathrm{NADP}^{+}$reduction. Catalase activity was quantified as described before [6]. Briefly, $20 \mu \mathrm{g}$ of protein extracts were taken in $50 \mathrm{mM}$ potassium phosphate buffer $(\mathrm{pH} 7.0)$ and $10 \mathrm{mM} \mathrm{H}_{2} \mathrm{O}_{2}$ at $25^{\circ} \mathrm{C}$ in $1 \mathrm{~mL}$ reaction mixture. The activity was monitored as a change in absorbance at $240 \mathrm{~nm}$ due to breakdown of $\mathrm{H}_{2} \mathrm{O}_{2}$. To get the reduced cICDH, it was incubated with $20 \mathrm{mM}$ DTT at $25^{\circ} \mathrm{C}$ for $1 \mathrm{~h}$. To remove excess dithiothreitol (DTT), protein samples were passed through a micro bio-spin column (Bio-Rad, Marnes-la-Coquette, France) after each treatment. The concentration of modified cICDH measured by absorbance at $340 \mathrm{~nm}$.

For recombinant cICDH enzymatic assay, the reaction was performed with $800 \mathrm{ng}$ of cICDH at $25^{\circ} \mathrm{C}$ in a $1000 \mu \mathrm{L}$ final volume containing $100 \mathrm{mM}$ phosphate buffer $(\mathrm{KOH}, \mathrm{pH} 7.5), 5 \mathrm{mM} \mathrm{MgCl}{ }_{2}$, $250 \mu \mathrm{M}$ of $\mathrm{NADP}^{+}$and $2.5 \mathrm{mM}$ DL-isocitric acid. The decrease in $\mathrm{NADP}^{+}$absorbance at $340 \mathrm{~nm}$ was monitored using a UV-1800 spectrophotometer (Shimadzu, Marne la Vallée, France). The molar extinction coefficient for $\mathrm{NADP}^{+}$of $6220 \mathrm{M}^{-1} \mathrm{~cm}^{-1}$ was used for the calculation. To obtain the $\mathrm{K}_{\mathrm{M}}$ for Isocitrate or $\mathrm{NADP}^{+}$, progress curves were recorded using varying concentrations of Isocitrate $(0-5 \mathrm{mM})$ or $\mathrm{NADP}^{+}(0-1 \mathrm{mM})$. The initial velocity (vi) for each substrate concentration was measured, and the $v i / E_{0}$ values were plotted and fitted with the Michaelis-Menten equation to obtain the kinetic parameters. Three independent replicates of $v i$ were measured for each substrate concentration.

For the reactivation of CICDH by TRXh, cICDH was incubated $30 \mathrm{~min}$ with recombinant TRXh $(4.59 \mu \mathrm{M})$ in the presence of NADPH $(0.125 \mathrm{mM})$ and NTRA $(0.5 \mu \mathrm{M})$. ICDH activity assay was performed as described earlier after diluting the mix 40 -fold. For cICDH reactivation by GRX, it was 
incubated for 30 min with recombinant GRX $(5 \mu \mathrm{M})$ in presence of NADPH $(0.125 \mathrm{mM})$, GSH $(0.8 \mathrm{mM})$ and GR $(5 \mu \mathrm{M})$. Then the mix was diluted 40 -fold and used for ICDH activity assay, as described above.

\subsection{Gel Filtration Chromatography}

His-ICDH recombinant proteins $(\sim 10 \mu \mathrm{g})$ were fractionated using Superose 12 (GE Healthcare, Buc, France) column equilibrated in Protein Buffer (50 mM Tris pH 7.5, $5 \mathrm{mM} \mathrm{MgCl}$ ) containing $150 \mathrm{mM} \mathrm{NaCl}$. The protein standards were aldolase (158 kDa), conalbumin $(75 \mathrm{kDa})$ and ovalbumin (43 kDa) (GE Healthcare).

\subsection{Liquid Chromatography-Tandem Mass Spectrometry (LC-MS/MS)}

Purified His-ICDH recombinant protein was dissolved in $8 \mathrm{M}$ urea / $0.1 \mathrm{M}$ ammonium bicarbonate buffer and thoroughly vortexed. The urea concentration was then lowered to $1 \mathrm{M}$ by dilution with fresh $0.1 \mathrm{M}$ ammonium bicarbonate, and proteins were digested in solution by addition of trypsin overnight at $37^{\circ} \mathrm{C}$. After acidification with formic acid, desalting and concentration of the peptides were carried out using a C18 Sep-Pak cartridge (Sep-pak Vac 1cc (50mg) tC18 cartridges, Waters, Guyancourt, France).

LC-MS/MS analyses were conducted on a nanoHPLC-Q Exactive Plus system (Thermo Fisher Scientific, Bremen, Germany). Peptide separation was performed on an ACQUITY UPLC BEH130 C18 column ( $250 \mathrm{~mm} \times 75 \mu \mathrm{m}$ with $1.7 \mu \mathrm{m}$ diameter particles, Waters). The solvent system consisted of $0.1 \%$ FA in water (solvent A) and $0.1 \%$ FA in ACN (solvent B). Peptides were eluted at $450 \mathrm{~nL} / \mathrm{min}$ with the following gradient of solvent B: from 1 to $8 \%$ over $2 \mathrm{~min}$, from 8 to $35 \%$ over $28 \mathrm{~min}$ and then $90 \%$ for $5 \mathrm{~min}$. The system was operated in positive mode using the following settings: MS1 survey scans $\left(\mathrm{m} / \mathrm{z} 300\right.$ to 1800) were performed at a resolution of 70000 with an AGC target of $3 \times 10^{6}$ and the maximum injection time was set to $50 \mathrm{~ms}$. MS/MS spectra were acquired at a resolution of 17500 . The MS2 AGC target was set to $1 \times 10^{5}$ and the maximum injection time was set to $100 \mathrm{~ms}$.

NanoLC-MS/MS data were searched using a local Mascot server (version 2.5.1, MatrixScience, London, UK) in an Arabidopsis thaliana protein sequences database downloaded from the TAIR site (TAIR10 version, Phoenix Bioinformatics, Fremont, CA, USA), to which decoy sequences were added using the in-house developed software tool MSDA [32]. Spectra were searched with a mass tolerance of $5 \mathrm{ppm}$ in MS and $0.07 \mathrm{Da}$ in MS/MS mode. One missed cleavage was tolerated. Oxidation of cysteine residues were specified as variable modifications. Spectra and fragmentation tables that have allowed identifying glutathionylated peptides are provided.

\subsection{Biotin Labeling of S-Nitrosylated Proteins}

The biotinylation of S-nitrosylated proteins resulting from the in vitro S-nitrosylation was detected using the Biotin Switch Test (BST) as described by reference [33] and with minor modifications. To achieve this, $2.19 \mu \mathrm{M}$ of recombinant wild-type cICDH or Cys-mutated version of $\mathrm{cICDH}$ (cICDH-C363S) was incubated with $1 \mathrm{mM}$ GSNO at room temperature in a reaction mixture called HEN buffer. HEN buffer contains protease inhibitor cocktail along with $25 \mathrm{mM}$ 4-(2-hydroxyethyl)-1-piperazineethanesulfonic acid (HEPES) [pH 7.7], $1 \mathrm{mM}$ Ethylenediaminetetraacetic acid (EDTA), and $0.1 \mathrm{mM}$ neocuproine. After $30 \mathrm{~min}$ of incubation, the reaction mixture was desalted on Pierce ${ }^{\mathrm{TM}}$ Zeba spin columns (Thermo Fisher Scientific, Dardilly, France). To perform the denitrosylation, the resulting protein-SNO were incubated for $45 \mathrm{~min}$ with either TRXh, NTRA, and NADPH or with GRXC, GSH, GR and NADPH. Protein S-nitrosylation was assessed using BST as described in reference [33], except for $20 \mathrm{mM}$ NEM being used to alkylate free thiols. Residual NEM was removed by centrifugation (minimum $2000 \mathrm{~g}, 20 \mathrm{~min}, 4^{\circ} \mathrm{C}$ ) with 2 volumes of $-20{ }^{\circ} \mathrm{C}$ acetone (pre-chilled). The supernatant was removed and pellets were resuspended in $0.1 \mathrm{~mL}$ of HENS buffer (HEN buffer containing 1\% SDS) $/ \mathrm{mg}$ protein. To achieve biotinylation, the resuspended proteins were incubated at room temperature for $1 \mathrm{~h}$ after adding $2 \mathrm{mM}$ biotin-HPDP and $1 \mathrm{mM}$ ascorbate. After removing biotin-HPDP, the precipitated proteins were resuspended in 
$0.1 \mathrm{~mL}$ of HENS buffer/mg of protein and 2 volumes of neutralization buffer $(20 \mathrm{~mm}$ HEPES, $\mathrm{pH} 7.7$, $100 \mathrm{~mm} \mathrm{NaCl}, 1 \mathrm{~mm}$ EDTA, and $0.5 \%$ Triton X-100). A total of $15 \mu \mathrm{L}$ of Streptravidin-agarose/mg of protein were added and incubated for $1 \mathrm{~h}$ at RT. The matrix was washed five times with 10 volumes of washing buffer ( $600 \mathrm{mM} \mathrm{NaCl}$ in neutralization buffer). The sample were centrifuged at $200 \mathrm{~g}$ for $5 \mathrm{~s}$ at room temperature between each wash. Finally, the bound proteins were eluted with $100 \mathrm{mM}$ $\beta$-mercaptoethanol in neutralization buffer.

To perform western blot analysis, SDS-PAGE sample buffer was added to agarose beads. SDS-PAGE gel was run after heating the samples to $70{ }^{\circ} \mathrm{C}$ for $10 \mathrm{~min}$. The samples separated on SDS-PAGE were transferred to nitrocellulose membranes. Western blots were probed with anti-His antibodies (Merck KGaA, Darmstadt, Germany).

\subsection{Bioinformatics Analyses}

The gene and protein sequences were obtained from the NCBI website (http:/ / www.ncbi.nlm. nih.gov, Rockville Pike, Bethesda MD, USA). ClustalW2 software (http:/ / www.ebi.ac.uk/Tools/msa/ clustalw2/, EMBL-EBI, Wellcome Genome Campus, Hinxton, Cambridgeshire, UK) was used to perform the multiple sequence alignments. Swiss Model software (http:/ / swissmodel.expasy.org/, Protein Structure Bioinformatics Group, Swiss Institute of Bioinformatics Biozentrum, University of Basel, Switzerland) was used for cICDH modeling by using human cytosolic ICDH sequence structure (PDB ID: 1T0L, [34]), and the Geneious 9.0 software (Biomatters ApS, Aarhus, Denmark) was used for the $3 \mathrm{D}$ representation.

\section{Results}

\subsection{Enzymatic Characterization of Cytosolic NADP-ICDH}

In order to characterize redox modifications on the cytosolic NADP-ICDH (cICDH, At1g65930), we produced the recombinant $\mathrm{cICDH}$ in $E$. coli. The predicted protein shows $77.4 \%$ and $85.2 \%$ identity with the mito/chloro and peroxisomal NADP-ICDH from $A$. thaliana, respectively. It also shares conserved cysteine residues with most plant and mammalian NADP-ICDH proteins (Supplemental Figure S1). To verify that cICDH is a genuine NADP-ICDH, the cDNA was cloned in an expression vector and purified using an introduced N-terminal His-tag. SDS/PAGE analysis of purified cICDH indicated a monomer corresponding to the predicated molecular mass of $48.3 \mathrm{kDa}$ calculated for cICDH, including the N-terminal His-tag (Supplemental Figure S2). The migration of the protein is not modified when the SDS/PAGE gel is run under reducing or non-reducing conditions. However, size exclusion chromatography indicated that purified cICDH eluted at a molecular weight of $\sim 90 \mathrm{kDa}$, suggesting that the native $\mathrm{cICDH}$ is present as a dimer coordinated by non-covalent interactions (Supplemental Figure S3). Analysis of the catalyzed reaction revealed Michaelis-Menten kinetics with a Km for the substrate isocitrate of $99 \mu \mathrm{M}$ and a $\mathrm{k}_{\text {cat }}$ of $4.93 \mathrm{~s}^{-1}$ (Figure 1A and Table 1). Km and $\mathrm{k}_{\text {cat }}$ for $\mathrm{NADP}^{+}$were estimated at $28 \mu \mathrm{M}$ and and a $\mathrm{k}_{\text {cat }}$ of $5.81 \mathrm{~s}^{-1}$ (Figure 1B). The optimal pH for cICDH activity was found to be in the range of 7.5 to 8.5 (Figure 1C).

Table 1. Steady-state enzymatic parameters for cICDH and cICDH-C297S.

\begin{tabular}{cccc}
\hline Recombinant Protein & $\boldsymbol{K}_{\boldsymbol{M}}$ Isocitrate $(\boldsymbol{\mu M})$ & $\boldsymbol{k}_{\text {cat }}$ Isocitrate $\left.\mathbf{s}^{\mathbf{- 1}}\right)$ & $\boldsymbol{k}_{\text {cat }} / \boldsymbol{K}_{\boldsymbol{M}}\left(\mathbf{M}^{\mathbf{- 1}} \mathbf{s}^{\mathbf{- 1}}\right)$ \\
\hline CICDH & 99 & 4.93 & $4.97 \times 10^{4}$ \\
cICDH-C297S & 95 & 4.31 & $4.54 \times 10^{4}$ \\
\hline
\end{tabular}



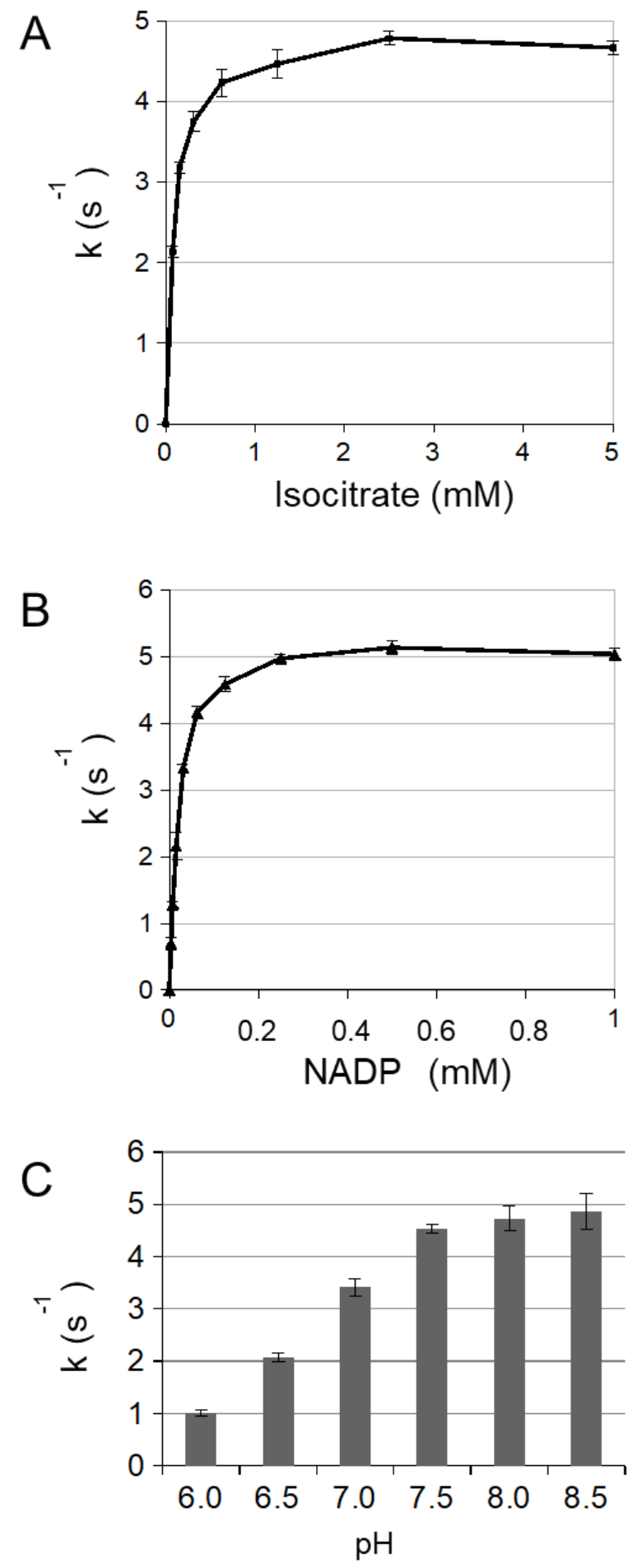

Figure 1. Cytosolic ICDH1 activity. ICDH (Isocitrate dehydrogenase) activity was measured for $800 \mathrm{ng}$ of ICDH by monitoring the change in absorbance at $340 \mathrm{~nm}$ due to the isocitrate-dependent rate of $\mathrm{NADP}^{+}$reduction at $25^{\circ} \mathrm{C}$ in $1 \mathrm{~mL}$ reaction medium containing $5 \mathrm{mM} \mathrm{MgCl} 2,250 \mu \mathrm{M}$ of $\mathrm{NADP}^{+}$and (A) different concentrations (0-5 mM) of DL-isocitric acid or (B) different concentrations (0-1 mM) of NADP in $100 \mathrm{mM}$ phosphate buffer (KOH, pH 7.5). (C) $2.5 \mathrm{mM}$ DL-isocitric acid in $100 \mathrm{mM}$ phosphate buffer at different $\mathrm{pH}(6-8.5)$. Error bars represent SE (Standard Error) $(n=3)$.

Next, we studied the effect of different oxidants on the activity of cICDH. Increasing concentrations of $\mathrm{H}_{2} \mathrm{O}_{2}$ hardly affected the enzyme activity (Figure 2A). However, both increasing concentrations of GSNO and GSSG progressively inhibited the cICDH activity, as did the combination of $\mathrm{H}_{2} \mathrm{O}_{2}$ and 
GSH (Figure 2). These latter treatments act as GSH donors which might modify cysteine residues by S-glutathionylation. Moreover, GSNO is also an excellent NO donor which can affect cysteine residues by S-nitrosylation.
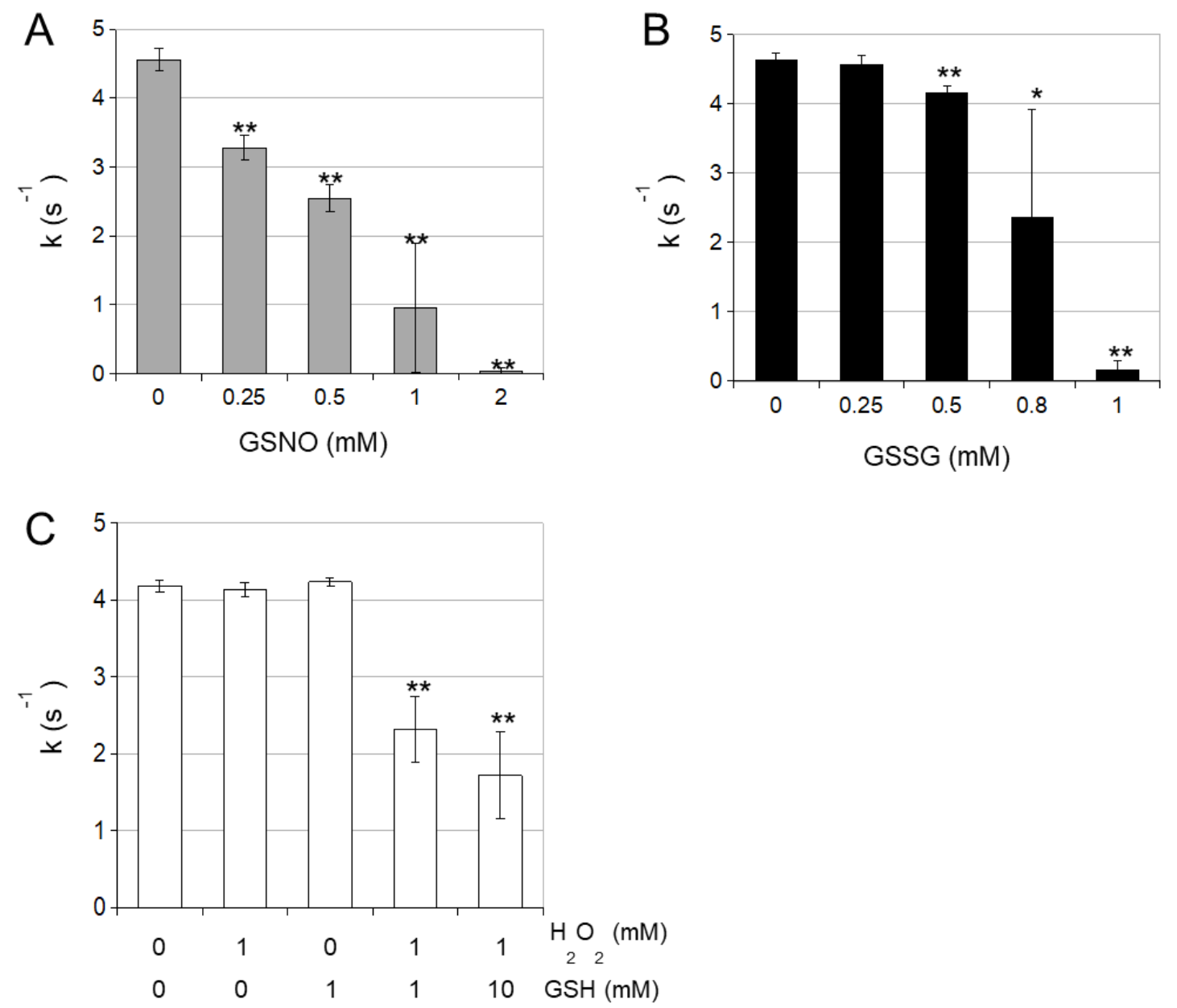

Figure 2. Cytosolic ICDH activity is sensitive to oxidation. $4.38 \mu \mathrm{M}(200 \mathrm{ng} / \mu \mathrm{L}) \mathrm{ICDH}$ were incubated with different concentrations of (A) $\mathrm{H}_{2} \mathrm{O}_{2} / \mathrm{GSH}$, (B) nitrosoglutathione (GSNO) or (C) oxidized glutathione (GSSG) for $15 \mathrm{~min}$ at $25^{\circ} \mathrm{C}$. This reaction mixture was diluted 250 times in reaction buffer during the assay. ICDH activity was measured for $800 \mathrm{ng}$ of ICDH at $25^{\circ} \mathrm{C}$ in $1 \mathrm{~mL}$ reaction medium containing $100 \mathrm{mM}$ phosphate buffer (KOH, pH 7.5), $5 \mathrm{mM} \mathrm{MgCl} 2,250 \mu \mathrm{M}$ of $\mathrm{NADP}^{+}$and $2.5 \mathrm{mM}$ DL-isocitric acid by monitoring the change in absorbance at $340 \mathrm{~nm}$ due to the isocitrate-dependent rate of $\mathrm{NADP}^{+}$reduction. Error bars represent SE $(n=3) .{ }^{*} p<0.05,{ }^{* *} p<0.01$ for statistical differences compared to non-treated samples (Student's $t$ test).

We investigated if cICDH can be glutathionylated/nitrosylated by treating His-cICDH protein with GSNO and analyzing samples by mass spectrometry. After trypsin digestion, peptides were analyzed by LC-MS/MS (Figure 3A). This reveals a glutathione adduct on two different Cys363-containing peptides (with and without a missed trypsin cleavage) detected thanks to a 305-Da mass increase of the modified peptides when compared to the non-modified peptide. These experiments attest that Cys363 can be glutathionylated in vitro. No other glutathionylated Cys residue was detected. The Cys363 glutathionylated site was confirmed and validated on independent triplicate experiments (Supplemental Figure S4). Then, we produced a cICDH-C363S mutant protein and tested it for glutathionylation in three same experimental conditions. No glutathionylated residue was detected in three different replicate experiments. Therefore, Cys363 is prone to S-glutathionylation 
upon GSNO treatment. By modeling cICDH, we established that Cys363 is probably not located in the close proximity of the cICDH active site (Figure 3B).
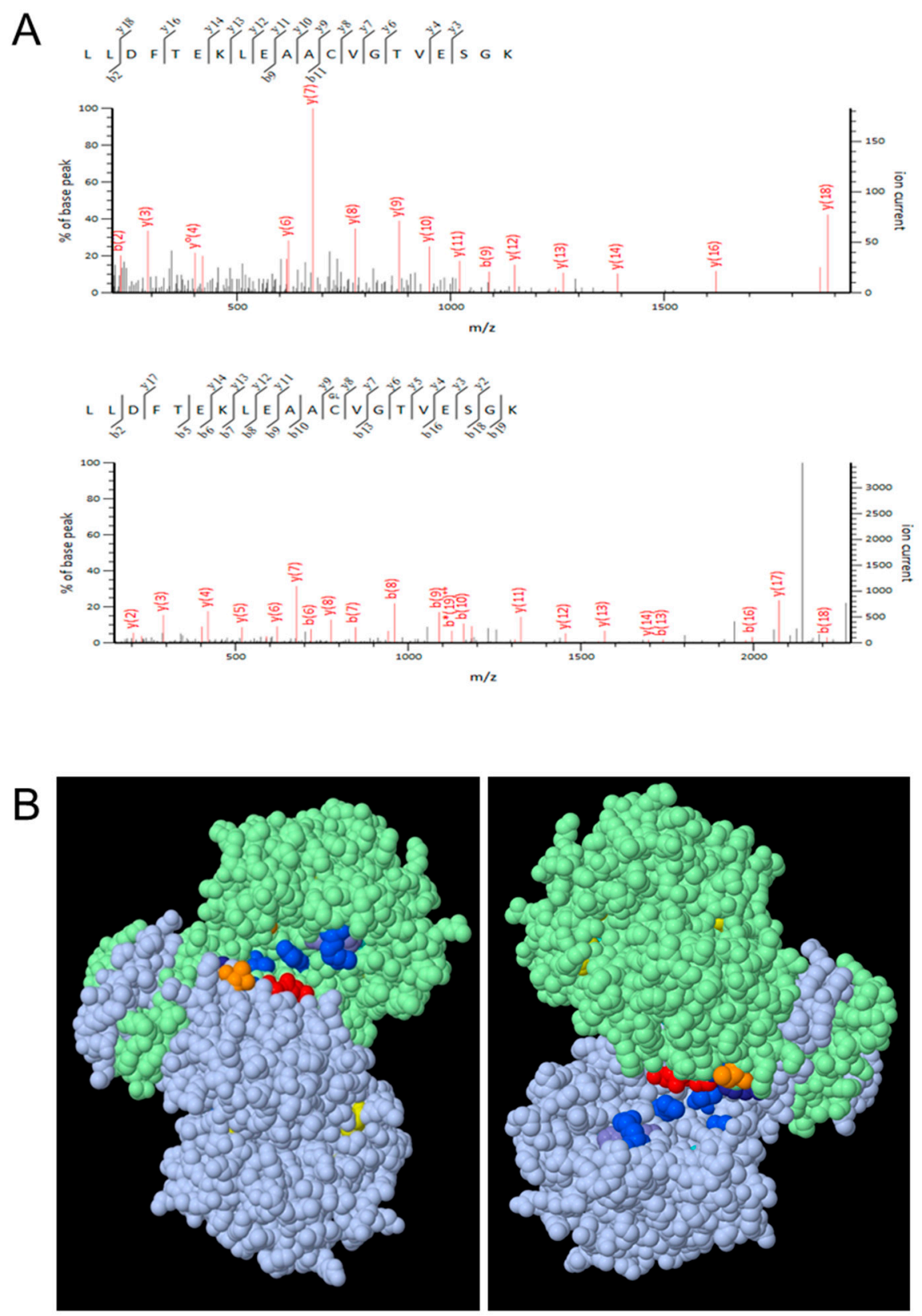

Figure 3. Glutathionylation of cICDH. (A) cICDH was treated or not with $1 \mathrm{mM}$ GSNO for $30 \mathrm{~min}$ at $25^{\circ} \mathrm{C}$. Samples were trypsin digested and analyzed by nanoLC-MSMS. The panels show fragmentation spectra matching peptides with either unmodified (top) or with glutathionylated C363 (bottom). The same glutathionylated residue was identified in three biological repetitions. (B) Modeled cICDH (residues 4-408) homodimer (grey and green chains) based on human cytosolic ICDH. Conserved amino acids (R111, R134, Y141, T214, D252, D279, R314, H315) with the most plant and mammalian NADP-ICDH proteins, in the active site pocket are shown in different colors depending on the nature of the residue: $\mathrm{R}$, blue; $\mathrm{Y}$, purple; $\mathrm{T}$, orange; $\mathrm{D}$, red; $\mathrm{H}$, grey. The conserved cysteine $\mathrm{C} 363$ in each chain is represented in yellow (arrowheads). In the right panel, the cICDH homodimer was rotated $180^{\circ}$.

We also performed a biotin-switch experiment to test if $\mathrm{cICDH}$ is S-nitrosylated. Treatment with GSNO leads to a specific biotin-switch signal, indicating that cICDH is S-nitrosylated in vitro (Figure 4A). To identify the nitrosylated residues, we subjected the cICDH-C363S mutant protein to 
the same experiment. No decrease of the biotin-switch signal was observed, which did not allow us to identify the S-nitrosylated Cys residues (Figure 4A).

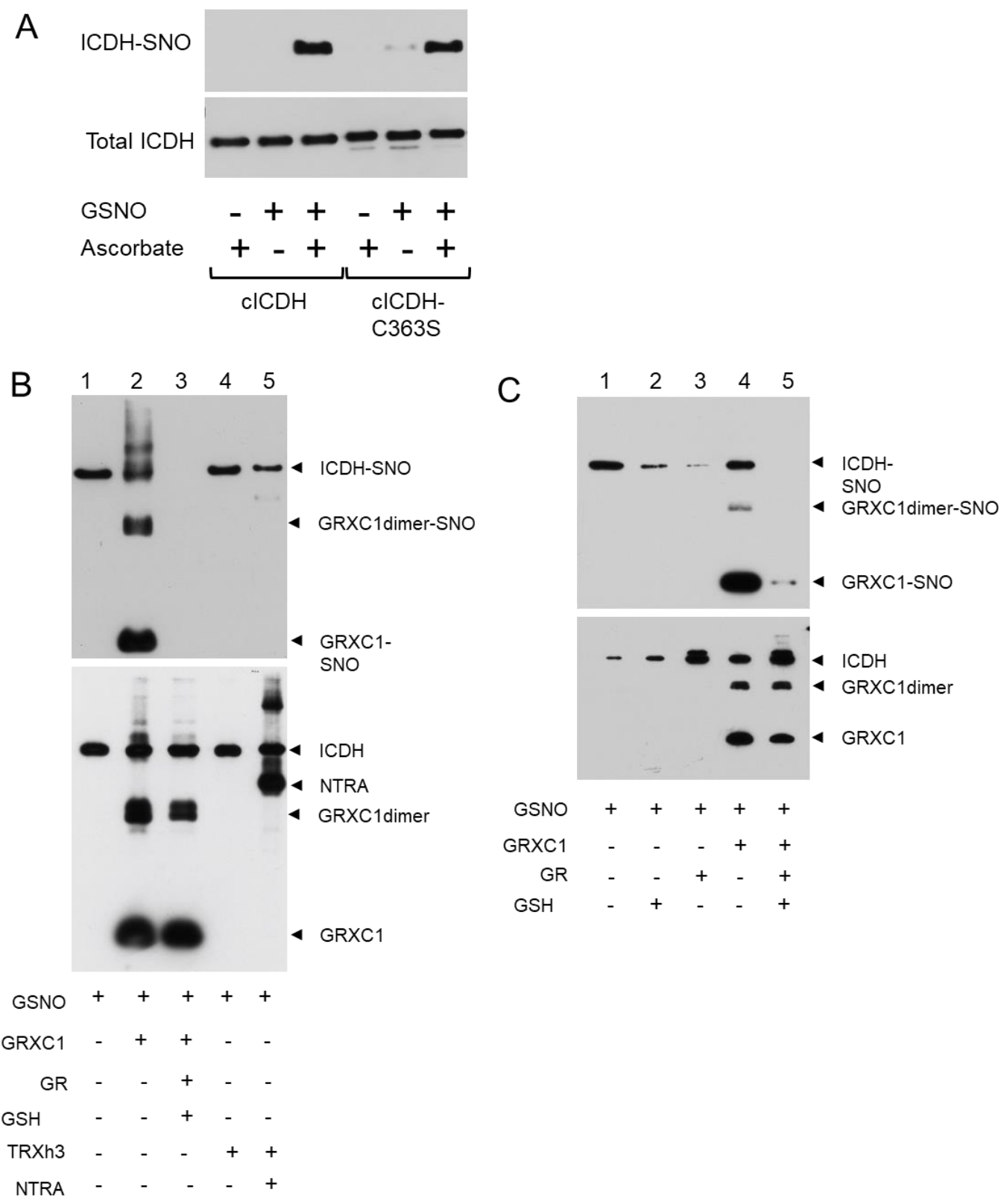

Figure 4. cICDH is S-nitrosylated and is denitrosylated by the GRX system. (A) $2.19 \mu \mathrm{M}$ of recombinant wild-type cICDH or Cys-mutated versions of cICDH (cICDH-C363S) were treated with or without $1 \mathrm{mM}$ GSNO for $30 \mathrm{~min}$ at $25^{\circ} \mathrm{C}$, and subjected to the biotin-switch assay in presence or absence of sodium ascorbate. (B) After treatment with GSNO $(1 \mathrm{mM})$, the protein was treated with GRXC1 $(5 \mu \mathrm{M})$ alone (lane 2), GRXC1, GSH (0.8 mM) and GR (0.45 $\mu \mathrm{M})$ (Lane 3), NTRA (3 $\mu \mathrm{M})$ alone (lane 4) and NTRA+TRXh3 $(4.59 \mu \mathrm{M})$ (lane 5) for $30 \mathrm{~min}$ at $25{ }^{\circ} \mathrm{C}$ and subjected to the biotin-switch assay in the presence of sodium ascorbate. (C) The same experimental design in the presence of GSH (0.8 $\mathrm{mM})$ (lane 2), GR (5 $\mu \mathrm{M})$ (lane 3), GrxC1 (5 $\mu \mathrm{M})$ (lane 4) and GRXC1+GR+GSH (lane 5). Afterwards, the proteins were separated by reducing SDS-PAGE and transferred onto nitrocellulose membrane. Total ICDH (bottom panel) or S-nitrosylated ICDH (top panel) was detected using an anti-His antibody.

Then, we examined the denitrosylation activity of thiol reductases by biotin switch (Figure 4B). When GSNO treated cICDH was further incubated by the recombinant cytosolic TRXh3 in the presence 
or absence of its physiological reducer NTRA, no denitrosylation activity was observed, suggesting that the TRX system was not able to remove SNO adducts from cICDH (Figure 4B). However, adding the GRX system to the reaction triggered the disappearing of the biotin switch signal on GSNO-treated cICDH, suggesting that the GRX-dependent thiol reduction system has a denitrosylation activity on cICDH (Figure 4B). By looking closer to this activity, we noticed that the denitrosylation activity needs the full GRX system (NADPH/GR/GSH/GRX) to be optimal (Figure 4C). Interestingly, while performing the biotin switch in presence of GRXC1, we noticed a strong signal on the GRXC1, suggesting that GRXC1 is prone to trans-nitrosylation (Figure 4B,C).

To test the function of Cys363 in cICDH activity, we examined the impact of the C363S point mutation on enzymatic activities. The cICDH C363S mutant had a Km of $95 \mu \mathrm{M}$ and a $\mathrm{k}_{\text {cat }}$ of $4.31 \mathrm{~s}^{-1}$ for the substrate isocitrate, which is similar to the wild-type protein, suggesting that the C363S mutation does not perturb the enzymatic characteristics of cICDH (Figure 5A and Table 1). However, cICDH C363S was found to be less affected by GSNO treatment than the wild-type enzyme, suggesting that S-nitrosylation/S-glutathionylation of Cys363 play a regulatory function for cICDH activity (Figure 5B).
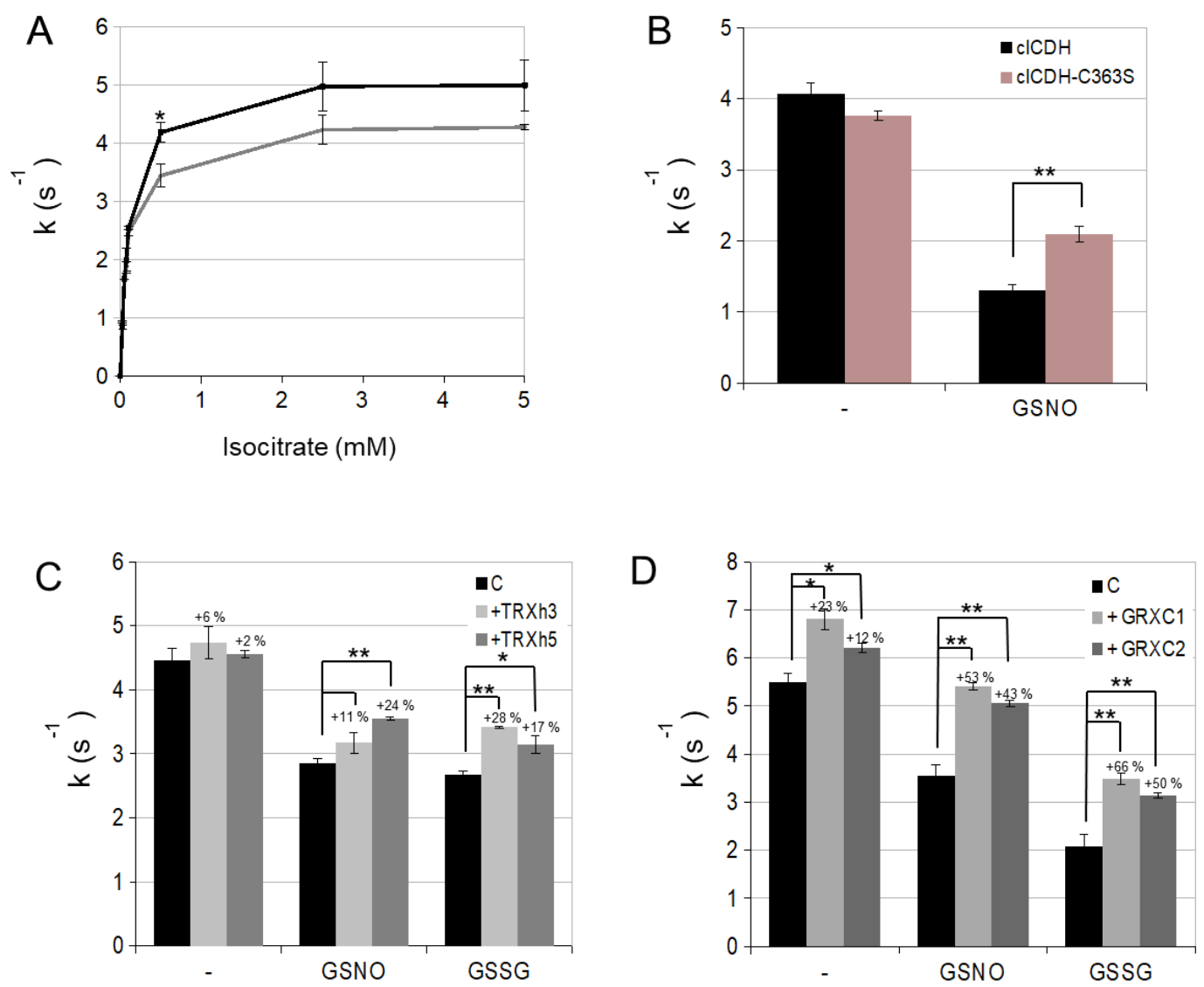

Figure 5. Cysteine-dependent regulation of cICDH activity. (A) ICDH activity was measured for $800 \mathrm{ng}$ of ICDH and ICDH-C363S by monitoring the change in absorbance of NADPH at $340 \mathrm{~nm}$ due to the isocitrate-dependent rate of $\mathrm{NADP}^{+}$reduction at $25^{\circ} \mathrm{C}$ in $1 \mathrm{~mL}$ reaction medium containing $5 \mathrm{mM}$ $\mathrm{MgCl}_{2}, 250 \mu \mathrm{M}$ of $\mathrm{NADP}^{+}$and different $(0-5 \mathrm{mM})$ concentrations of DL-isocitric acid. (B) ICDH were incubated with $1 \mathrm{mM} \mathrm{GSNO}$ and measured in the same conditions than described previously. (C) $800 \mathrm{ng}$ of cICDH were incubated with $0.5 \mathrm{mM}$ GSNO, $0.75 \mathrm{mM}$ GSSG for $15 \mathrm{~min}$ at $25^{\circ} \mathrm{C}$. The samples were diluted 2-fold and then incubated with $1 \mathrm{mM}$ NADPH in the presence of NTRA $(3 \mu \mathrm{M})$ and TRXh3 or TRXh5 $(4.59 \mu \mathrm{M})(\mathrm{D})$ Same experimental design as in (C), but in presence of GR $(0.45 \mu \mathrm{M})$, GSH $(0.8 \mathrm{mM})$ and GRXC1 or GRXC2 $(5 \mu \mathrm{M})$. Error bars represent SE $(n=3) .{ }^{*} p<0.01,{ }^{* *} p<0.001$ for statistical differences compared to non-treated samples (Student's $t$ test). 


\section{2. cICDH Activity Is Restored by Glutaredoxins}

After having established that cICDH activity is affected by glutathionylation on Cyc363, we wished to determine if cICDH activity could be restored by thiol reduction pathways. For this purpose, we subjected GSNO-treated cICDH to different thiol reductases: thioredoxins are major disulfide reductases, but have also been shown to have denitrosylation capacities [35]. However, they are generally not able to reduce S-glutathionylated cysteine adducts. On the contrary, glutaredoxins exhibit a major deglutathionylation activity [8]. We found that cytosolic GRXC1 and GRXC2 are more efficient than TRXh3 and TRXh5 to restore cICDH activity, which is consistent with a deglutathionylation activity of GRXC1 and GRXC2 (Figure 5C,D). Collectively, our data suggest that cICDH activity is inhibited by S-glutathionylation on Cys363 and that GRXC1 and GRXC2 are able to reverse this effect through their deglutathionylation activity.

\subsection{Enzyme Activities Are Affected in Mutants}

In order to study whether cICDH activity is redox sensitive in planta, we measured ICDH activities in leaves from two-weeks old plants of different Arabidopsis mutants. While exhibiting no phenotypic perturbations on the rosette growth, the cytosolic icdh KO mutant shows a marked decrease $(-60 \%)$ of NADP-ICDH activities (Figure 6A). This confirmed previous data showing that the cytosolic ICDH contributed to the major pool of the shoot extractible NADP-ICDH activity. Nevertheless, this contribution seems somehow less than reported previously $(-90 \%)$, possibly due differences in growth conditions or developmental stage of the plants or to the contribution of organellar NADP-ICDH activities [6]. NADP-dependent ICDH activities were also consistently decreased in the cat2 mutant (Figure 6A), which is impaired in the major isoform of the peroxisomal $\mathrm{H}_{2} \mathrm{O}_{2}$ detoxification enzyme Catalase 2 (Supplemental Figure S5), suggesting that NADP-ICDH activities are affected by oxidizing conditions. Interestingly, the steady-state ICDH activity was even more affected $(-90 \%)$ in the icdh cat 2 double mutant, suggesting that other cellular NADP-ICDH isoforms might be affected by the cat 2 mutation. Moreover, the NADP-ICDH was also slightly decreased in the gr1 involved in the reduction of the cytosolic glutathione pool $[23,36]$. The latter mutant accumulates higher levels of oxidized glutathione than wild-type plants, suggesting that NADP-ICDH activities might be sensitive to perturbed glutathione conditions [23]. The NADP-dependent ICDH activities are more strikingly affected in the cat2 gr1 mutant, which accumulates much higher GSSG levels as cat2 and gr1 single mutants [24].

We also examined NADP-ICDH activity in different mutants affected in the NO metabolism [22,26-28]. NADP-ICDH activities were decreased in the gsnor mutant which accumulates a high level of GSNO. As expected from in vitro experiments, treatment of wild-type protein extracts with GSNO strikingly inhibits the activity. Surprisingly, NADP-ICDH steady-state activity is not affected in the nox1 mutant which overaccumulates NO, suggesting a specific impact of GSNO on ICDH (Figure 6B). This was further confirmed by treating wild-type protein extracts with the NO donor sodium nitroprusside (SNP), which did not affect the NADP-ICDH activities. Finally, the activity is not perturbed in noa1, nia1 nia2 and noa1, nia1 nia2 mutants in which the biosynthesis of NO is alleviated (Figure 6B). 

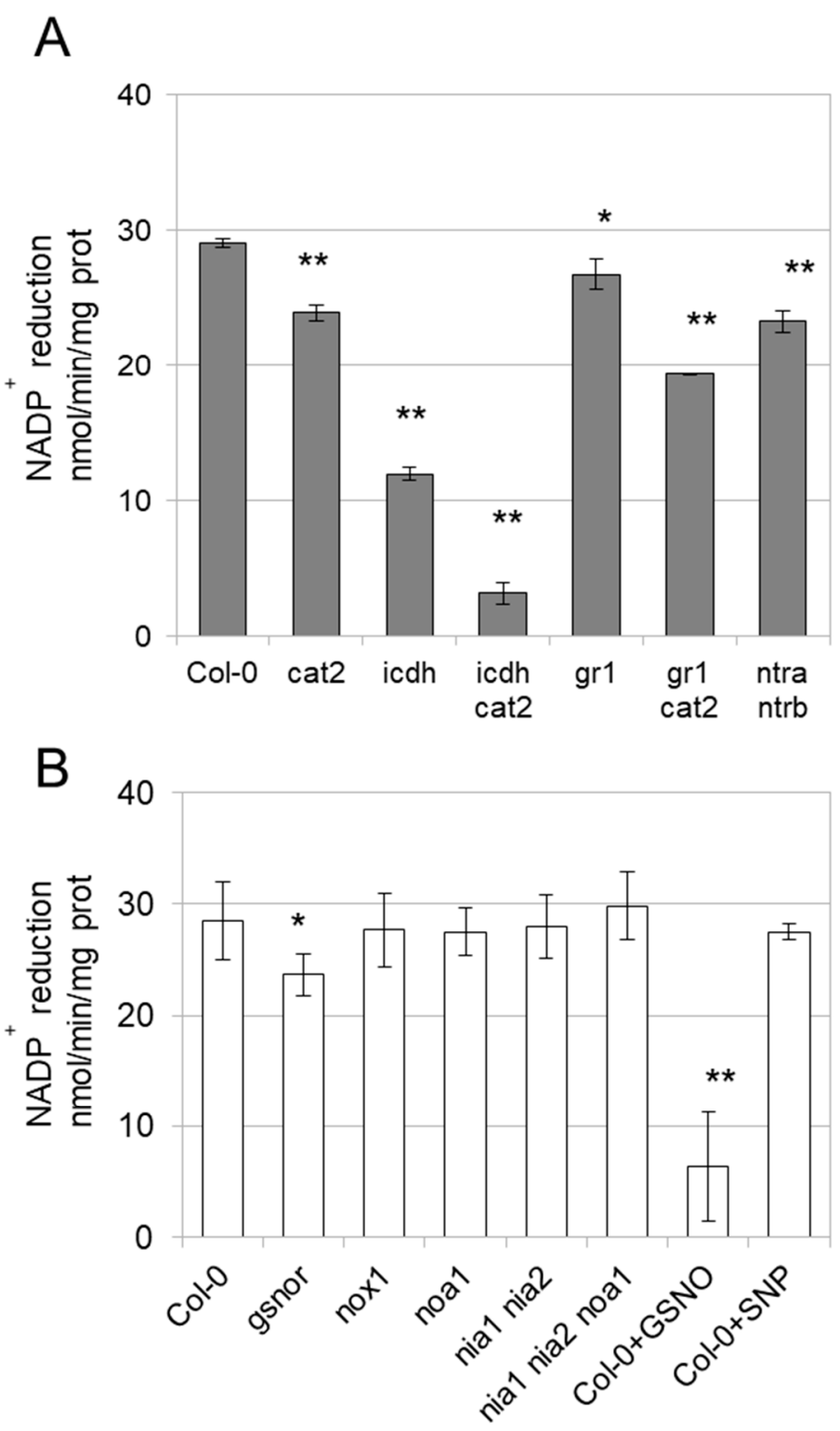

Figure 6. ICDH activity in planta. (A) ICDH activity was measured for $40 \mu \mathrm{g}$ of protein extracts at $25{ }^{\circ} \mathrm{C}$ by monitoring the change in absorbance at $340 \mathrm{~nm}$ due to the isocitrate-dependent rate of $\mathrm{NADP}+$ reduction. Wild-type (Col-0) or mutant A. thaliana plants were grown in soil in a controlled growth chamber $\left(180 \mu \mathrm{E} \mathrm{m}^{-2} \mathrm{~s}^{-1}, 16 \mathrm{~h}\right.$ day $/ 8 \mathrm{~h}$ night, $22{ }^{\circ} \mathrm{C} 55 \% \mathrm{RH}$ day, $20{ }^{\circ} \mathrm{C} 60 \% \mathrm{RH}$ night $)$ for 2 weeks. (B) Same design as in (A). In Col-O+GSNO and Col-0+SNP, protein extracts of wild-type plants were treated with $1 \mathrm{mM}$ GSNO or SNP for $30 \mathrm{~min}$ before performing activity tests. Error bars represent $\mathrm{SE}(n=3) .{ }^{*} p<0.01,{ }^{* *} p<0.001$ for statistical differences compared to non-treated samples (Student's $t$ test).

\section{Discussion}

Plant ICDH are part of a multigenic family (Supplemental Figure S1). Mitochondrial NAD-dependent ICDH involved in TCA cycle are composed of 6 genes, two of them are encoding catalytic subunits, and the four others for regulatory subunits [37]. NADP-ICDH are found in the cytosol, peroxisome, mitochondria and chloroplast. Each of these compartments only contains a single isoform, one of them being dually targeted to chloroplasts and mitochondria $[4,6,38]$. Different arguments are in favor of redox regulation of ICDH: (i) ICDHs were found to exhibit sulfenylated [12,13], glutathionylated [14] or nitrosylated [15] Cys upon oxidizing conditions (ii) ICDH isoforms including the $\mathrm{CICDH}$ were previously identified as interactors of thiols reductases TRX 
and GRX in different proteomic analyses [16-20,39]. (iii) conserved Cys residues are found in ICDH isoforms of most organisms, including mammals (iiii) mammalian cytosolic ICDH have been shown to be regulated by S-nitrosylation $[9,10]$, which we also confirmed in our study (Supplemental Figure S6). Supporting these assumptions, we found that cytosolic NADP-ICDH activities are affected in GSNO, GSSG and $\mathrm{H}_{2} \mathrm{O}_{2} / \mathrm{GSH}$-supplied purified cICDH as well as in mutants exhibiting perturbed GSNO, GSSG or $\mathrm{H}_{2} \mathrm{O}_{2}$ reduction. While these oxidizing conditions seem not to induce intermolecular disulfide bonds in the recombinant enzyme as previously shown for other metabolic enzymes [29], the single Cys363 residue was consistently found to be glutathionylated after GSNO treatments. Interestingly, the Cys363 is also conserved in other ICDH isoforms (mitochondrial, peroxisome and chloroplastic/mitochondrial) as well as in cytosolic ICDH isoforms from other organisms (Supplemental Figure S1), suggesting that Cys363 redox regulation might occur in other ICDH isoforms.

Intriguingly, our ICDH model suggests that Cys363 residue is not located close to the ICDH active site and thus seems not to interfere directly with the catalytic activity. A likely hypothesis would be that upon oxidation, a major conformational change occurs, which might change the activity of the enzyme. The fact that the C363S point mutation does not affect the activity of the recombinant cICDH (Figure 5A) does not really support this hypothesis, assuming that a Cys to Ser mutation mimics Cys oxidation. Another hypothesis is that Cys363 glutathionylation (or nitrosylation) occurs that protects the residue from an irreversible overoxidation triggered by oxidative stress [29].

Interestingly, while having no significant impact on cICDH activity, the C363S mutation does affect the sensitivity of the enzyme to GSNO inhibition, which indicates that Cys363 is targeted by GSNO. We also showed that this single mutation does not fully alleviates the sensitivity to GSNO, suggesting that other residues might be involved. Thus, the mechanism by which oxidation affects cICDH activity needs to be further explored.

It has to be underlined that, while other Cys are found in the cICDH sequence, no other oxidized residues have been identified in our MS/MS experiments under GSNO treatment. Nevertheless, biotin-switch experiments have clearly identified S-nitrosylated residues upon GSNO treatments, suggesting that cICDH is also S-nitrosylated. Whether Cys363 is nitrosylated and if other residues are nitrosylated cannot be concluded from the non-quantitative biotin-switch technique performed on the cICDH-C363S protein and would need additional point mutation experiments. Consistently, an isotope-coded affinity tags (ICAT) approach identified three other S-nitrosylated residues (Cys 75 and Cys269) in cICDH in Arabidopsis [40]. Residue Cys75 of Arabidopsis NADP-ICDH activity has been found to be differentially S-nitrosylated in response to salt stress [41]. And Tyr392 has also been reported to be the only nitrated residue in pea plants and is possibly responsible for the inhibition of catalytic activity following treatment with SIN-1 [42]. These residues are conserved in NADP-ICDH of plants and other organisms (Supplemental Figure S1). While preparing this manuscript, Munos-Vargas et al. (2018) showed that NO donors peroxynitrite $\left(\mathrm{ONOO}^{-}\right)$, S-nitrosocyteine (CysNO) and DETA-NONOate also inhibited NADP-ICDH activity in sweet pepper. Munos-Vargas et al. (2018) established by in silico analysis of the tertiary structure of sweet pepper NADP-ICDH activity (UniProtKB ID A0A2G2Y555) that residues Cys133 and Tyr450 are the most likely potential targets for S-nitrosation and nitration, respectively [43].

Therefore, future mutagenesis experiments should establish the contribution of other residues than Cys363 in the redox regulation of the protein. As S-nitrosylation is a rather unstable modification, the fact that we do not identified S-nitrosylated residues in our LC-MS/MS is not surprising. Interestingly, biotin switch experiments indicate that the TRX system is unable to act as a denitrosylation system for cICDH, as shown for other substrates, including in plants [44-46]. In contrast, the GRX system is efficient and needs the complete NADPH/GR/GSH/GRXC1 system to be optimal at least in vitro. This is consistent with the observation that the GRXC1 or GRXC2 thiol reduction system is more efficient than the TRX system in rescuing the inhibitory effect of GSNO or GSSG on cICDH activity, suggesting that deglutathionylation activity of GRX is involved in the redox mechanism of cICDH regulation. 
Our NADP-ICDH activity analyses in the icdh mutant confirm that cICDH contributes to the major part $(\sim 60 \%)$ of the NADP-ICDH activity. The other $\sim 40 \%$ of the overall extractible activity likely provide from organellar NADP-ICDH activities. These proportions are somehow different than those reported previously, in which cICDH contributed to over $80 \%$ of the extractible activity in potato and Arabidopsis [5,6]. These differences might be due to different growth conditions (in vitro vs soil growth), developmental stages or tissues (10 day-old plantlets vs 3 week-old adult leaves) analyzed. Nevertheless, the observation that the NADP-ICDH activity is more affected in the cat 2 icdh double mutant compared to the icdh single mutant suggests that organellar ICDH isoforms might be affected in by the cat 2 mutation. Nevertheless, we cannot rule out that the decrease in the NADP-ICDH activity in the cat 2 mutant also relies on other modifications induced by oxidative distress.

ICDH is an important enzyme in 2-OG synthesis, as the carbon backbone of ammonia to glutamate by the GS/GOGAT pathway [1]. But it also provides reduced NAD(P)H equivalents to redox enzymes like GR or NTR. Interestingly, both cat2, gr1 and cat2 gr1 double mutants exhibit decreased NADPH production $[23,25]$, which might rely on a decreased NADP-ICDH activity. Moreover, the lower ICDH activity we found in the cytosolic gr1 mutant and to a higher extent in the cat 2 gr1 double mutant is possibly due to the high accumulation of oxidized glutathione found in these mutants. Consistently, the gsnor mutant impaired in the reduction of GSNO also exhibits lower ICDH activity, although this effect is less pronounced than an exogenous treatment by GSNO. Intriguingly, both in exogenous treatment with SNP and in the nox1 mutant which accumulate high levels of NO, the ICDH activity is not affected, suggesting a distinct role of GSNO and NO in ICDH regulation. Such observations were reported previously and suggested that GSNO and NO have distinct substrates [45-47]. In the present work, the difference between impact on ICDH activity caused by gsnor and nox 1 could result from the fact that GSNO is also an efficient glutathione donor for cICDH S-glutathionylation.

\section{Conclusions}

Collectively, our data add another evidence of the potential redox regulation of primary carbon and nitrogen metabolism through the regulation of the cytosolic isocitrate dehydrogenase. We also highlight the importance the GRX-dependent thiol reduction systems as a potential actor in fine-tuning the redox regulation of NADP-ICDH activity. While we clearly demonstrate that the enzyme can be modified by glutathionylation in vitro, future experiments are needed to demonstrate that this redox regulation actually occurs in vivo in response to environmental clues.

Supplementary Materials: The following are available online at http:/ /www.mdpi.com/2076-3921/8/1/16/s1, Figure S1: Alignement of NADP-ICDH sequence from different eukaryotics, Figure S2: Recombinant cICDH and cICDH-C363S, Figure S3: Recombinant cICDH is dimeric, Figure S4: Fragmentation tables of cICDH peptides identified with glutathionylated cysteines on Cys363., Figure S5: Catalase activity in planta, Figure S6: Human cytosolic ICDH activity is sensitive to NO donors, Table S1: Primers used in this study.

Author Contributions: Conceptualization, A.K.N., G.N. and J.-P.R.; Data curation, C.R.; Funding acquisition, G.N. and J.-P.R.; Investigation, A.K.N., L.B. and C.C.; Project administration, J.-P.R.; Resources, A.M. and G.N.; Supervision, J.-P.R.; Writing-Original draft, J.-P.R.; Writing-Review \& Editing, A.K.N., C.R., C.C. and G.N.

Funding: This research was funded by [Agence Nationale de la Recherche] grant number [12-BSV6-0011].

Acknowledgments: This work was supported by grants from the Centre National de la Recherche Scientifique and the Agence Nationale de la Recherche (ANR-Blanc Cynthiol 12-BSV6-0011). This work has been supported by LabEx Agro and LabEx TULIP.

Conflicts of Interest: The authors declare no conflicts of interest.

\section{References}

1. Hodges, M. Enzyme redundancy and the importance of 2-oxoglutarate in plant ammonium assimilation. J. Exp. Bot. 2002, 53, 905-916. [CrossRef] [PubMed] 
2. Lemaitre, T.; Urbanczyk-Wochniak, E.; Flesch, V.; Bismuth, E.; Fernie, A.R.; Hodges, M. NAD-dependent isocitrate dehydrogenase mutants of Arabidopsis suggest the enzyme is not limiting for nitrogen assimilation. Plant Physiol. 2007, 144, 1546-1558. [CrossRef] [PubMed]

3. Møller, I.M.; Rasmusson, A.G. The role of NADP in the mitochondrial matrix. Trends Plant Sci. 1998, 3, $21-27$.

4. Galvez, S.; Bismuth, E.; Sarda, C.; Gadal, P. Purification and Characterization of Chloroplastic NADP-Isocitrate Dehydrogenase from Mixotrophic Tobacco Cells (Comparison with the Cytosolic Isoenzyme). Plant Physiol. 1994, 105, 593-600. [CrossRef]

5. Kruse, A.; Fieuw, S.; Heineke, D.; Müller-Röber, B. Antisens inhibition of cytosolic NADP-dependent isocitrate dehydrogenase in transgenic potato plants. Planta 1998, 205, 82-91. [CrossRef]

6. Mhamdi, A.; Mauve, C.; Gouia, H.; Saindrenan, P.; Hodges, M.; Noctor, G. Cytosolic NADP-dependent isocitrate dehydrogenase contributes to redox homeostasis and the regulation of pathogen responses in Arabidopsis leaves. Plant Cell Environ. 2010, 33, 1112-1123. [PubMed]

7. Benhar, M.; Forrester, M.T.; Stamler, J.S. Protein denitrosylation: Enzymatic mechanisms and cellular functions. Nat. Rev. Mol. Cell Biol. 2009, 10, 721-732. [CrossRef]

8. Meyer, Y.; Belin, C.; Delorme-Hinoux, V.; Reichheld, J.-P.; Riondet, C. Thioredoxin and glutaredoxin systems in plants: Molecular mechanisms, crosstalks, and functional significance. Antioxid. Redox Signal. 2012, 17, 1124-1160. [CrossRef]

9. Yang, E.S.; Richter, C.; Chun, J.-S.; Huh, T.-L.; Kang, S.-S.; Park, J.-W. Inactivation of NADP(+)-dependent isocitrate dehydrogenase by nitric oxide. Free Radic. Biol. Med. 2002, 33, 927-937. [CrossRef]

10. Lee, J.H.; Yang, E.S.; Park, J.-W. Inactivation of NADP+-dependent isocitrate dehydrogenase by peroxynitrite. Implications for cytotoxicity and alcohol-induced liver injury. J. Biol. Chem. 2003, 278, 51360-51371. [CrossRef]

11. Shin, S.W.; Oh, C.J.; Kil, I.S.; Park, J.-W. Glutathionylation regulates cytosolic NADP+-dependent isocitrate dehydrogenase activity. Free Radic. Res. 2009, 43, 409-416. [CrossRef] [PubMed]

12. Akter, S.; Huang, J.; Bodra, N.; De Smet, B.; Wahni, K.; Rombaut, D.; Pauwels, J.; Gevaert, K.; Carroll, K.; Van Breusegem, F.; et al. DYn-2 Based Identification of Arabidopsis Sulfenomes. Mol. Cell. Proteom. 2015, 14, 1183-1200. [CrossRef] [PubMed]

13. Waszczak, C.; Akter, S.; Eeckhout, D.; Persiau, G.; Wahni, K.; Bodra, N.; Van Molle, I.; De Smet, B.; Vertommen, D.; Gevaert, K.; et al. Sulfenome mining in Arabidopsis thaliana. Proc. Natl. Acad. Sci. USA 2014, 111, 11545-11550. [CrossRef] [PubMed]

14. Zaffagnini, M.; Bedhomme, M.; Groni, H.; Marchand, C.H.; Puppo, C.; Gontero, B.; Cassier-Chauvat, C.; Decottignies, P.; Lemaire, S.D. Glutathionylation in the photosynthetic model organism Chlamydomonas reinhardtii: A proteomic survey. Mol. Cell. Proteom. 2012, 11. [CrossRef]

15. Morisse, S.; Zaffagnini, M.; Gao, X.-H.; Lemaire, S.D.; Marchand, C.H. Insight into protein S-nitrosylation in Chlamydomonas reinhardtii. Antioxid. Redox Signal. 2014, 21, 1271-1284. [CrossRef] [PubMed]

16. Balmer, Y.; Vensel, W.H.; Tanaka, C.K.; Hurkman, W.J.; Gelhaye, E.; Rouhier, N.; Jacquot, J.-P.; Manieri, W.; Schürmann, P.; Droux, M.; et al. Thioredoxin links redox to the regulation of fundamental processes of plant mitochondria. Proc. Natl. Acad. Sci. USA 2004, 101, 2642-2647. [CrossRef]

17. Marchand, C.; Le Maréchal, P.; Meyer, Y.; Miginiac-Maslow, M.; Issakidis-Bourguet, E.; Decottignies, P. New targets of Arabidopsis thioredoxins revealed by proteomic analysis. Proteomics 2004, 4, 2696-2706. [CrossRef]

18. Marchand, C.; Le Maréchal, P.; Meyer, Y.; Decottignies, P. Comparative proteomic approaches for the isolation of proteins interacting with thioredoxin. Proteomics 2006, 6, 6528-6537. [CrossRef]

19. Rouhier, N.; Villarejo, A.; Srivastava, M.; Gelhaye, E.; Keech, O.; Droux, M.; Finkemeier, I.; Samuelsson, G.; Dietz, K.J.; Jacquot, J.-P.; et al. Identification of plant glutaredoxin targets. Antioxid. Redox Signal. 2005, 7, 919-929. [CrossRef]

20. Pérez-Pérez, M.E.; Mauriès, A.; Maes, A.; Tourasse, N.J.; Hamon, M.; Lemaire, S.D.; Marchand, C.H. The Deep Thioredoxome in Chlamydomonas reinhardtii: New Insights into Redox Regulation. Mol. Plant 2017, 10, 1107-1125. [CrossRef]

21. He, Y.; Tang, R.-H.; Hao, Y.; Stevens, R.D.; Cook, C.W.; Ahn, S.M.; Jing, L.; Yang, Z.; Chen, L.; Guo, F.; et al. Nitric oxide represses the Arabidopsis floral transition. Science 2004, 305, 1968-1971. [CrossRef] [PubMed]

22. Lee, U.; Wie, C.; Fernandez, B.O.; Feelisch, M.; Vierling, E. Modulation of nitrosative stress by S-nitrosoglutathione reductase is critical for thermotolerance and plant growth in Arabidopsis. Plant Cell 2008, 20, 786-802. [CrossRef] [PubMed] 
23. Mhamdi, A.; Hager, J.; Chaouch, S.; Queval, G.; Han, Y.; Taconnat, L.; Saindrenan, P.; Gouia, H.; Issakidis-Bourguet, E.; Renou, J.-P.; et al. Arabidopsis GLUTATHIONE REDUCTASE1 plays a crucial role in leaf responses to intracellular hydrogen peroxide and in ensuring appropriate gene expression through both salicylic acid and jasmonic acid signaling pathways. Plant Physiol. 2010, 153, 1144-1160. [CrossRef]

24. Reichheld, J.-P.; Khafif, M.; Riondet, C.; Droux, M.; Bonnard, G.; Meyer, Y. Inactivation of thioredoxin reductases reveals a complex interplay between thioredoxin and glutathione pathways in Arabidopsis development. Plant Cell 2007, 19, 1851-1865. [CrossRef]

25. Queval, G.; Issakidis-Bourguet, E.; Hoeberichts, F.A.; Vandorpe, M.; Gakière, B.; Vanacker, H.; Miginiac-Maslow, M.; Van Breusegem, F.; Noctor, G. Conditional oxidative stress responses in the Arabidopsis photorespiratory mutant cat2 demonstrate that redox state is a key modulator of daylength-dependent gene expression, and define photoperiod as a crucial factor in the regulation of $\mathrm{H}_{2} \mathrm{O}_{2}$-induced cell death. Plant J. 2007, 52, 640-657. [PubMed]

26. Lozano-Juste, J.; León, J. Enhanced abscisic acid-mediated responses in nia1nia2noa1-2 triple mutant impaired in NIA/NR- and AtNOA1-dependent nitric oxide biosynthesis in Arabidopsis. Plant Physiol. 2010, 152, 891-903. [CrossRef] [PubMed]

27. Hu, W.-J.; Chen, J.; Liu, T.-W.; Liu, X.; Chen, J.; Wu, F.-H.; Wang, W.-H.; He, J.-X.; Xiao, Q.; Zheng, H.-L. Comparative proteomic analysis on wild type and nitric oxide-overproducing mutant (nox1) of Arabidopsis thaliana. Nitric Oxide 2014, 36, 19-30. [CrossRef] [PubMed]

28. Chen, R.; Sun, S.; Wang, C.; Li, Y.; Liang, Y.; An, F.; Li, C.; Dong, H.; Yang, X.; Zhang, J.; et al. The Arabidopsis PARAQUAT RESISTANT2 gene encodes an S-nitrosoglutathione reductase that is a key regulator of cell death. Cell Res. 2009, 19, 1377-1387. [CrossRef]

29. Huang, J.; Niazi, A.K.; Young, D.; Rosado, L.A.; Vertommen, D.; Bodra, N.; Abdelgawwad, M.R.; Vignols, F.; Wei, B.; Wahni, K.; et al. Self-protection of cytosolic malate dehydrogenase against oxidative stress in Arabidopsis. J. Exp. Bot. 2018, 69, 3491-3505. [CrossRef] [PubMed]

30. Gibon, Y.; Blaesing, O.E.; Hannemann, J.; Carillo, P.; Höhne, M.; Hendriks, J.H.M.; Palacios, N.; Cross, J.; Selbig, J.; Stitt, M. A Robot-based platform to measure multiple enzyme activities in Arabidopsis using a set of cycling assays: Comparison of changes of enzyme activities and transcript levels during diurnal cycles and in prolonged darkness. Plant Cell 2004, 16, 3304-3325. [CrossRef] [PubMed]

31. Daloso, D.M.; Müller, K.; Obata, T.; Florian, A.; Tohge, T.; Bottcher, A.; Riondet, C.; Bariat, L.; Carrari, F.; Nunes-Nesi, A.; et al. Thioredoxin, a master regulator of the tricarboxylic acid cycle in plant mitochondria. Proc. Natl. Acad. Sci. U.A 2015, 112, E1392-E1400. [CrossRef] [PubMed]

32. Carapito, C.; Burel, A.; Guterl, P.; Walter, A.; Varrier, F.; Bertile, F.; Van Dorsselaer, A. MSDA, a proteomics software suite for in-depth Mass Spectrometry Data Analysis using grid computing. Proteomics 2014, 14, 1014-1019. [CrossRef] [PubMed]

33. Forrester, M.T.; Foster, M.W.; Benhar, M.; Stamler, J.S. Detection of protein S-nitrosylation with the biotin-switch technique. Free Radic. Biol. Med. 2009, 46, 119-126. [CrossRef] [PubMed]

34. Xu, X.; Zhao, J.; Xu, Z.; Peng, B.; Huang, Q.; Arnold, E.; Ding, J. Structures of human cytosolic NADP-dependent isocitrate dehydrogenase reveal a novel self-regulatory mechanism of activity. J. Biol. Chem. 2004, 279, 33946-33957. [CrossRef] [PubMed]

35. Kneeshaw, S.; Keyani, R.; Delorme-Hinoux, V.; Imrie, L.; Loake, G.J.; Le Bihan, T.; Reichheld, J.-P.; Spoel, S.H. Nucleoredoxin guards against oxidative stress by protecting antioxidant enzymes. Proc. Natl. Acad. Sci. USA 2017, 114, 8414-8419. [CrossRef] [PubMed]

36. Marty, L.; Siala, W.; Schwarzländer, M.; Fricker, M.D.; Wirtz, M.; Sweetlove, L.J.; Meyer, Y.; Meyer, A.J.; Reichheld, J.-P.; Hell, R. The NADPH-dependent thioredoxin system constitutes a functional backup for cytosolic glutathione reductase in Arabidopsis. Proc. Natl. Acad. Sci. USA 2009, 106, 9109-9114. [CrossRef]

37. Lemaitre, T.; Hodges, M. Expression analysis of Arabidopsis thaliana NAD-dependent isocitrate dehydrogenase genes shows the presence of a functional subunit that is mainly expressed in the pollen and absent from vegetative organs. Plant Cell Physiol. 2006, 47, 634-643. [CrossRef]

38. Corpas, F.J.; Barroso, J.B.; Sandalio, L.M.; Palma, J.M.; Lupiáñez, J.A.; del Río, L.A. Peroxisomal NADP-Dependent Isocitrate Dehydrogenase. Characterization and Activity Regulation during Natural Senescence. Plant Physiol. 1999, 121, 921-928. [CrossRef] 
39. Montrichard, F.; Alkhalfioui, F.; Yano, H.; Vensel, W.H.; Hurkman, W.J.; Buchanan, B.B. Thioredoxin targets in plants: The first 30 years. J Proteomics 2009, 72, 452-474. [CrossRef]

40. Fares, A.; Rossignol, M.; Peltier, J.-B. Proteomics investigation of endogenous S-nitrosylation in Arabidopsis. Biochem. Biophys. Res. Commun. 2011, 416, 331-336. [CrossRef]

41. Källberg, M.; Wang, H.; Wang, S.; Peng, J.; Wang, Z.; Lu, H.; Xu, J. Template-based protein structure modeling using the RaptorX web server. Nature Protocols 2012, 7, 1511-1522. [CrossRef] [PubMed]

42. Begara-Morales, J.C.; Chaki, M.; Sánchez-Calvo, B.; Mata-Pérez, C.; Leterrier, M.; Palma, J.M.; Barroso, J.B.; Corpas, F.J. Protein tyrosine nitration in pea roots during development and senescence. J. Exp. Bot. 2013, 64, 1121-1134. [CrossRef] [PubMed]

43. Muñoz-Vargas, M.A.; González-Gordo, S.; Cañas, A.; López-Jaramillo, J.; Palma, J.M.; Corpas, F.J. Endogenous hydrogen sulfide $(H 2 S)$ is up-regulated during sweet pepper (Capsicum annuum L.) fruit ripening. In vitro analysis shows that NADP-dependent isocitrate dehydrogenase (ICDH) activity is inhibited by $\mathrm{H} 2 \mathrm{~S}$ and NO. Nitric Oxide 2018, 81, 36-45. [CrossRef] [PubMed]

44. Benhar, M.; Forrester, M.T.; Hess, D.T.; Stamler, J.S. Regulated protein denitrosylation by cytosolic and mitochondrial thioredoxins. Science 2008, 320, 1050-1054. [CrossRef]

45. Benhar, M. Application of a Thioredoxin-Trapping Mutant for Analysis of the Cellular Nitrosoproteome. Meth. Enzymol. 2017, 585, 285-294. [PubMed]

46. Kneeshaw, S.; Gelineau, S.; Tada, Y.; Loake, G.J.; Spoel, S.H. Selective protein denitrosylation activity of Thioredoxin- $h 5$ modulates plant Immunity. Mol. Cell 2014, 56, 153-162. [CrossRef]

47. Tada, Y.; Spoel, S.H.; Pajerowska-Mukhtar, K.; Mou, Z.; Song, J.; Wang, C.; Zuo, J.; Dong, X. Plant immunity requires conformational changes [corrected] of NPR1 via S-nitrosylation and thioredoxins. Science 2008, 321, 952-956. [CrossRef] [PubMed]

(C) 2019 by the authors. Licensee MDPI, Basel, Switzerland. This article is an open access article distributed under the terms and conditions of the Creative Commons Attribution (CC BY) license (http://creativecommons.org/licenses/by/4.0/). 